Pamiętnik Literacki 2018, 2, s. 103-118

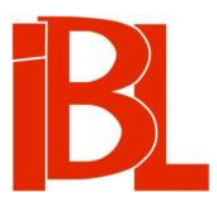

\title{
Malta Jana Potockiego
}

\author{
Tadeusz Wojciech Lange
}




\section{2. $\begin{array}{lllllllllllllllllll} & \mathrm{M} & \mathrm{A} & \mathrm{T} & \mathrm{E} & \mathrm{R} & \mathrm{I} & \mathrm{A} & \mathrm{E} & \mathrm{Y} & \mathrm{I} & \mathrm{N} & \mathrm{O} & \mathrm{T} & \mathrm{A} & \mathrm{T} & \mathrm{K} & \mathrm{I}\end{array}$}

Pamiętnik Literacki CIX, 2018, z. 2, PL ISSN 0031-0514

DOI:10.18318/pl.2018.2.5

TADEUSZ WOJCIECH LANGE Uniwersytet im. Adama Mickiewicza, Poznań

\section{MALTA JANA POTOCKIEGO}

Wszyscy prawdziwi miłośnicy dzieła Jana Potockiego wiedzą, iż w młodości spędził on prawie dwa lata na Malcie, gdzie jako kawaler maltański walczył z piratami; echa tego pobytu znajdujemy zreszta w kilku opowieściach Rękopisu znalezionego $w$ Saragossie. Niniejszy esej jest próbą pokazania czytelnikowi, jak wyglądała wyspa w czasie, w którym przebywał na niej późniejszy twórca postaci maltańczyków w swojej szkatułkowej powieści.

Miasto stoi na półwyspie, między dwoma najwspanialszymi portami na świecie, których bronią fortyfikacje niemal nie do zdobycia. Port położony w południowo-wschodniej części miasta jest większy. Wcina się on na dwie mile w głąb wyspy i jest tak głęboki i otoczony tak wysokimi nabrzeżami i umocnieniami, że - jak nas zapewniano - nawet przy najbardziej sztormowej pogodzie największe okręty mogą tu stać nieomal bez użycia cumy. Ten piękny port podzielony jest na pięć odrębnych, równie bezpiecznych basenów, zdolnych pomieścić ogromną liczbę jednostek ${ }^{1}$.

Tak zaczyna swój opis Wielkiego Portu ${ }^{2}$ w stolicy Malty, Valletcie, przybyły tu z Sycylii Szkot, podróżnik, a być może także angielski szpieg Patrick Brydone, który odwiedził wyspe 9 lat przed pojawieniem się na niej Jana Potockiego. I ciagnie dalej:

Wejście do portu nie ma więcej niż ćwierć mili szerokości i strzeżone jest po obu stronach przez baterie dział, które rozerwałyby najpotężniejszy okręt na strzępy, zanim zdołałby tam wpłynąć. Ponadto chronione jest przez poczwórne, piętrowe baterie, $z$ których jedna jest typu fleur d'eau, czyli na poziomie wody. Baterie są uzbrojone w około 80 dział największego dostępnego tu kalibru; moim zdaniem więc port ten można uznać za nie do zdobycia, i Turcy dobrze o tym wiedzą ${ }^{3}$.

Jeżeli takie wrażenie zrobił port wojenny Valletty na przedstawicielu morskiej potęgi, możemy założyć, że napełnił on jeszcze większym podziwem 18-letniego porucznika armii austriackiej, bądź co bądź szczura lądowego, gdy późnym latem lub jesienią roku $1779^{4}$ zawitał on na Maltę po raz pierwszy.

1 P. Bryd o ne, A Tour through Sicily and Malta, in a Series of Letters to William Beckford esq. of Somerly in Suffolk. T. 1. London 1775, s. 342-343.

2 Nazwa ta w czasach zakonu brzmiała Porto Grande, obecnie Grand Harbour (ang.), Il-Port il-Kbir (malt.).

$3 \quad$ Brydone, op. cit., s. 343.

$4 \quad$ Zaskakujące jest to, że dokładniejszych dat pobytów Potockiego na Malcie nie udało się ustalić nawet tak dociekliwym badaczom biografii hrabiego jak F. Ros s et i D. Triaire (Jan Potocki. Biografia. Przeł. A. W a sil ew s ka. Warszawa 2007). Stwierdzili oni, że Potocki na początku lata 


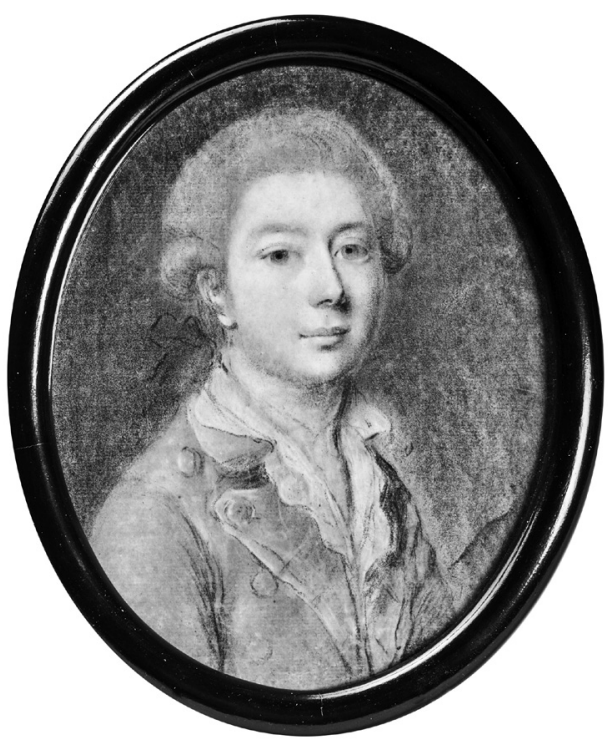

1. Jan Potocki w roku 1778. Pastel na papierze, nieznany malarz wiedeński. Muzeum-Zamek w Łańcucie

Nie da się jednak wykluczyć, że statek, który przywiózł młodego hrabiego, ze względów sanitarnych przycumował do nabrzeża Valletty od drugiej strony, w drugim ze wspomnianych portów:

Port po północnej stronie miasta, chociaż używany tylko przez rybaków i jako miejsce kwarantanny, w każdej innej części świata uznany by został za nieoceniony, jako że również broniony jest przez umocnienia. Pośrodku portu znajduje się wyspa, na której zbudowano fort i lazzaretto ${ }^{5}$.

Mowa tu o porcie Marsamxett ${ }^{6}, \mathrm{z}$ Wyspą Manoela (malt. Il-Gżira Manoel), nazwaną tak na cześć wielkiego mistrza Antónia Manoela de Vilheny, budowniczego wymienionego fortu. Lazzaretto służyło jako miejsce 40-dniowej kwarantanny jeszcze około roku 1810, kiedy to poddano jej m.in. George'a Byrona odbywającego swoje grand tour.

Uszkodzone podczas drugiej wojny światowej zabytki Wyspy Manoela popadły stopniowo w ruinę, ale są obecnie pod opieką konserwatorów.

Potocki nie pozostawił potomnym ani relacji ze swojego pobytu na Malcie, ani jej opisu; można zgadnąc, że poważniejsze geograficzne, etnograficzne i archeologiczne zainteresowania narodziły się u niego w wieku dojrzalszym, i że młodego człowieka zajmowała przede wszystkim rycerska legenda kawalerów maltańskich, którą nie tyle chciał opisywać, ile wziąć w niej udział. Należy zatem założyć, że szukający wrażeń i bohaterskiej sławy hrabia, by być bliżej wojennego portu, zamieszkał właśnie w stolicy, tak przedstawionej przez współczesnego mu Brydone’a:

w 1779 roku przebywał w Krainie oraz że w tym samym roku popłynął z Malty do Tunezji. Wiadomo jednak, iż na początku roku 1780 był na wyspie $z$ powrotem.

5 Brydone, op. cit., s. 344.

6 W owym czasie port ten zwano Porto di Marza Muscietto. 
Jako że Vallettę zbudowano na wzgórzu, żadna z ulic z wyjątkiem głównej nie jest pozioma. Wszystkie są wyłożone białym kamieniem, który nie tylko wytwarza moc kurzu, ale jego barwa tak razi w oczy, że większość tutejszych ludzi ma dziwnie słaby wzrok. Główne budynki to pałac wielkiego mistrza, lecznica, arsenał, gospody czy też hotele Siedmiu Języków i wielki kościół św. Jana. Pałac to zacna, choć prosta budowla, a wielki mistrz (który nad przepych przedkłada komfort) mieszka tam wygodniej i przestronniej niż którykolwiek z książąt Europy, może z wyjątkiem władcy Sardynii. Wielkie schody tego pałacu są lepsze i praktyczniejsze niż jakiekolwiek inne mi znane ${ }^{7}$.

Pałac wielkich mistrzów istnieje do dzisiaj i jest siedziba prezydenta Republiki Malty i, do niedawna, jej parlamentu. Stoi on przy Republic Street (malt. Triq Ir-Repubblika), która w tamtych czasach nazywała się Strada San Giorgio.

Lecznica to Sacra Infermeria, niezwykle istotny element wszystkich siedzib szpitalniczego, w końcu, zakonu św. Jana, od Jerozolimy, poprzez Cypr i Rodos, po Maltę. Opieka medyczna zawsze prezentowała najwyższy dostępny zachodniej cywilizacji poziom. Budynek Świętej Lecznicy służy obecnie jako międzynarodowy ośrodek konferencyjny - Mediterranean Conference Centre.

W czasach Potockiego na tyłach Pałacu Wielkich Mistrzów znajdował się zakonny arsenał; dzisiaj resztki jego zawartości wystawiane są w dawnych pałacowych stajniach od frontu.

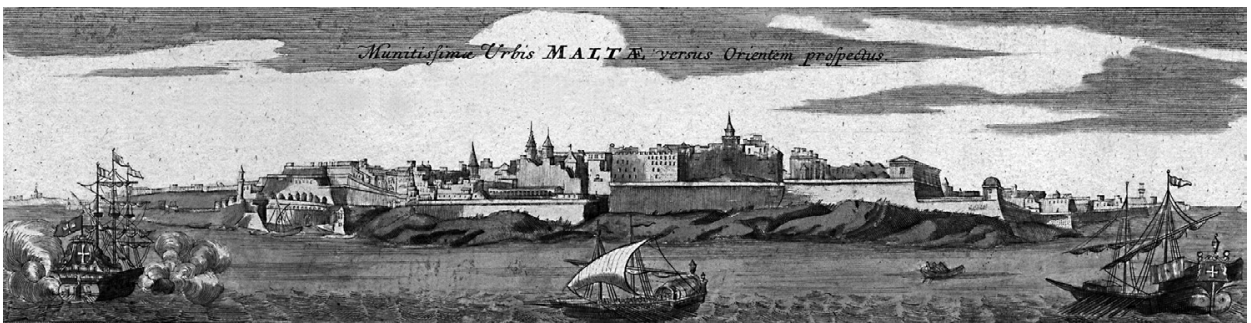

2. Valletta od strony Wielkiego Portu. Ryc. Johanna Homanna, 1720

Wspomniane „gospody”, czyli auberges, pełniły funkcję swoistych internatów dla przebywających na wyspie kawalerów z poszczególnych „języków” (langues), czyli grup narodowościowych $\mathrm{w}$ średniowiecznym jeszcze ich rozumieniu. Owe „Siedem Języków” to: Prowansja, Owernia, Francja, Włochy, Aragonia, Kastylia i Niemcy. Pierwotnie "gospody” znajdowały się w miasteczku Birgu (zwanym też Vittoriosa), na półwyspie po stronie Wielkiego Portu. Po wielomiesięcznym oblężeniu Malty przez Turków w roku 1565 postanowiono przenieść stolicę na znacznie rozleglejszy półwysep Sciberras, gdzie wybudowano Vallettę, nazwaną tak dla upamiętnienia bohatera owego Wielkiego Oblężenia, wielkiego mistrza Jeana Parisota de la Valette. Jako miasto zaplanowane od podstaw, ma ono siatkę ulic przecinających się pod kątem prostym. Projektantem stolicy i jej fortyfikacji był architekt papieski, asystent Michała Anioła, Francesco Laparelli. Kiedy ów padł ofiara zarazy, budowę miasta dokończył jego maltański pomocnik, Girolamo Cassar. Ten sam miejscowy architekt był również odpowiedzialny za projekt i budowę nowych "gospód". 


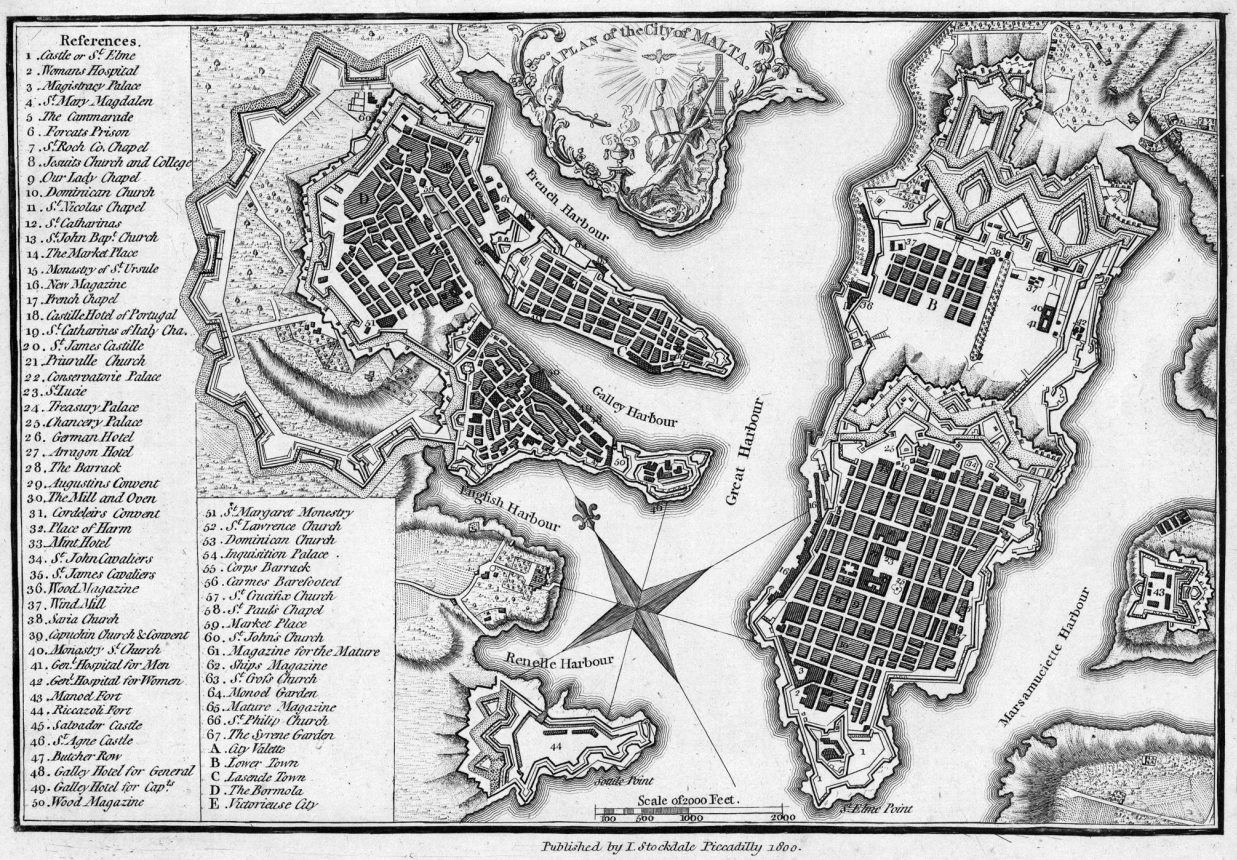

3. Plan Valletty $z$ roku 1800

Z siedmiu istniejących w czasach Potockiego, do dziś przetrwały cztery: gospoda Kastylii (obecnie siedziba premiera Malty), gospoda Aragonii (gdzie teraz rezyduje wicepremier do spraw prezydencji Unii Europejskiej) gospoda Prowansji (współcześnie Muzeum Archeologiczne) i gospoda Włoch (dziś Departament Turystyki). Rosset i Triaire zastanawiają się, czy Potocki mógł zamieszkać w nieistniejącej już dziś auberge Niemiec ${ }^{8}$; istotnie, polscy maltańczycy przypisani byli do ,języka” niemieckiego, ale hrabia wszak kawalerem maltańskim jeszcze nie był, musiał więc, przynajmniej na początku pobytu, wynająć jakąś kwaterę w mieście.

Cassar zaprojektował również wspomnianą przez Brydone’a świątynię. Oddajmy głos szkockiemu podróżnikowi:

Kościół św. Jana jest wspaniały, a jego posadzka uchodzi za najkosztowniejszą w świecie. W całości składa się ona $\mathrm{z}$ tablic nagrobnych wykonanych z kawałków najlepszych marmurów, porfiru, lapis lazuli innych rodzajów cennego kamienia, znacznym kosztem nad wyraz starannie ze sobą połączonych i przedstawiających w czymś na kształt mozaiki herb, insygnia itp. osób, których nazwiska mają upamiętnić. Spadkobiercy wielkich mistrzów i komandorów od dawna konkurują ze sobą w wystawności tych pomników 9 .

Kościół zachował się w opisanym przez Brydone’a stanie i obecnie pełni funkcję konkatedry (malt. Kon-Katidral ta' San Ġwann), będąc zarazem jedną z większych atrakcji turystycznych wyspy. Nie bez wpływu na to jest wiszące w kościele Ścięcie 
św. Jana pędzla Caravaggia, który przez pewien czas bawił na Malcie i na krótko został nawet przyjęty do zakonu.

Wspomniani w zacytowanym fragmencie komandorowie to w zakonnej hierarchii maltańczycy piastujący urząd zwierzchnika i beneficjenta komandorii, czyli folwarku lub klucza folwarków pozyskanych przez zakon drogą darowizny od pobożnego władcy bądź innego właściciela ziemskiego. Zwierzchnictwo nad grupa komandorii na danym obszarze sprawował baliw (bailli), który z kolei podlegał przeorowi, ponieważ, tak jak inne religijne zgromadzenia, zakon maltański dzielił się na przeoraty. Na każdy wspomniany już ,język” składało się na ogół kilka takich przeoratów. Świeżo w czasach Potockiego powołany przeorat polski był za mały, by stworzyć własną langue, dlatego początkowo przypisano go do najbliższego terytorialnie ,języka” - niemieckiego. Kilka lat po pobycie hrabiego na wyspie Polskę przyporządkowano do nowo powstałego „języka” anglo-bawarskiego.

Potocki z całą pewnością uczestniczył w życiu religijnym zgromadzenia. Protestant Brydone zostawił nam opis uroczystego nabożeństwa, którego był świadkiem we wspomnianej świątyni:

Wydaje się ono przeładowane paradami i ceremoniałem w większym stopniu, niż widziałem w jakimkolwiek innym katolickim kraju. Całe to nieustanne przyklękanie przed ołtarzem, całowanie ręki przeora, podtrzymywanie jego szat przez niższych rangą księży, okadzanie posiadaczy Wielkiego Krzyża i ignorowanie biedniejszych kawalerów zdało mi się wysoce komiczne i tak bardzo odległe od czystości i prostoty kultu, który stanowi istotę prawdziwego chrześcijaństwa ${ }^{10}$.

Posiadaczem Wielkiego Krzyża stawał się zasłużony i wiekowy na ogół maltańczyk. Tak wyróżnionych członków zakonu traktowano ze szczególnym szacunkiem.

Ciekawy i dość niepochlebny opis obyczajów wyżej postawionych kawalerów maltańskich przekazał nam Julian Ursyn Niemcewicz, który był na Malcie dwa lata po Potockim:

Mało jest na wyspie szlachty, i to ubogiej [...], przecież mnóstwo komandorów, bogatych bailly czyni ją bogatą i pieniężną. W kawalerach zbrojnych mnichów uważać można; taż sama co w klasztorach wyniosłość i zazdrość: ubóstwo i ambicja sprowadzają kawalerów do Malty, albo żeby być żywionymi kosztem zakonu lub by wcześniej torować sobie drogę do wielkiego mistrzostwa. Bogaci komandorowie i bailly nie mający żon i familii, dla górzystości miasta nie mogący trzymać ekwipażów, dochody swoje obracają na stoły. Jakoż w biesiadach nigdzie podobnego zbytku widzieć nie można ${ }^{11}$.

Tym, co z pewnością zainteresowało Potockiego, który znany był później z otwartości umysłu, była opisana przez Szkota religijna tolerancja na wyspie w całości podległej katolickiemu zakonowi:

Pomimo rzekomej bigoterii Maltańczyków, duch tolerancji jest tu tak silny, że ostatnio wybudowano na wyspie meczet dla zaprzysięgłych wrogów, Turków. Nieszczęśni niewolnicy mogą w nim praktykować swoją religię w pokoju. Niedawno zdarzyło się, że kilku młodych nierobów zakłóciło ich modły; natychmiast wtrącono ich za to do więzienia i surowo ukarano ${ }^{12}$.

Swoich obserwacji Brydone nie ograniczał do stolicy Malty:

Wyspa pokryta jest wiejskimi domami i wioskami, oprócz których znajduje się tam siedem miast.

J. U. N i e m c ew i c z, Pamiętniki czasów moich. Gdańsk 2000, s. 87-88. 
Tak je przynajmniej nazywaja, ale tylko dwa, Valletta i Cita Vecchia, w jakikolwiek sposób zasługują na to miano. Każda wioska ma zacny kościół, gustownie wykończony, ozdobiony marmurowymi posagami oraz gobelinami, bogato wyposażony w srebrne naczynia. W życiu nie widziałem równie przyjemnych dla oka wiejskich kościołów ${ }^{13}$.

Cita Vecchia to dzisiejsza Mdina, znana też jako Silent City, stare, warowne miasto położone około $13 \mathrm{~km}$ na wschód od Valletty. Brydone tak opisuje zwiedzanie Mdiny i okolic, które z pewnością stało się udziałem także Potockiego:

Tego dnia udaliśmy się na wyprawę przez wyspę w powozach ciagniętych przez pojedyncze muły - jedynych środkach lokomocji, które oferuje wyspa. Nasi powożący mówili wyłącznie po arabsku, który jest językiem maltańskiego gminu; wierzcie mi, że niewiele skorzystaliśmy z tych konwersacji. Najpierw udaliśmy się do starożytnego miasta Melita, które znajduje się blisko środka wyspy i z którego widać całą Maltę. Utrzymują, że przy dobrej pogodzie widać też część Berberii i Sycylię. Miasto jest silne obwarowane [...]. Katedra jest pięknym kościołem i chociaż jest ogromnych rozmiarów, jest w całości obwieszona pąsowym adamaszkiem bogato zdobionym złotem. Katakumby, położone nieopodal miasta, są niezwykłym dziełem. Podobno ciagnna się na 15 mil pod ziemią; jednakowoż trzeba to przyjąc od przewodników na wiarę, ponieważ sprawdzenie tego byłoby zbyt ryzykowne ${ }^{14}$.

Wspomniane przez Brydone'a czterokołowe powozy, zwane carrozzin, dziś ciągnięte przez nieduże tutejsze koniki, są jedną z lokalnych turystycznych atrakcji i stanowią odpowiednik używanych u nas dorożek.

Język maltański to odmiana arabskiego $z$ włoskimi i francuskimi wtrętami, datującymi się z czasów kawalerów maltańskich. Zapisywany jest zmodyfikowanym alfabetem łacińskim, ale właściwie nie miał formy pisanej wtedy, gdy Potocki odwiedził wyspę. Maltańskim, który jest urzędowym językiem na Malcie na równi $\mathrm{z}$ angielskim, posługuje się dziś około $2 / 3$ mieszkańców archipelagu. Za czasów kawalerów początkowo językiem zakonu na wyspie był włoski, za bytności Potockiego zaś, wskutek przeważającej liczby Francuzów, w powszechnym użyciu był język francuski.

Berberia to w tym wypadku dzisiejsza Libia lub Tunezja.

Katedra w Mdinie istniała tam jeszcze przed przybyciem zakonu, stąd główny kościół stolicy ma rangę konkatedry.

Mdina tradycyjnie zamieszkiwana jest przez starą maltańską arystokrację, i tak też było w czasach pobytu tam Potockiego, który w Rękopisie znalezionym w Saragossie ustami jednej ze swoich postaci wspomina „kilka szlacheckich rodzin wyspiarskich":

bynajmniej nie wchodzą [one] do zakonu i nie mają żadnych stosunków z kawalerami jakiego bądź stopnia. Uznają one tylko najwyższą władzę wielkiego mistrza i kapituły, składającej jego radę ${ }^{15}$.

Ibidem, s. 340.

Ibidem, s. 351-352.

J. P o t o c ki, Rękopis znaleziony $w$ Saragossie. Przygot., przypisy L. Ku ku ls ki. T. 2. Warszawa 1976, s. 237. Wybór tej edycji w przekładzie E. Chojeckie go wynika wyłącznie z sentymentu autora niniejszego artykułu. Rozdziały „maltańskie” znajdują się tu w „dniach” 53, 54 i 55. W najnowszym wydaniu Rękopisu znalezionego $w$ Saragossie, opracowanym przez F. Ro s s e ta i D. Tria ir e' a (Nowe tłumaczenie ostatniej wersji autorskiej z 1810 roku. Przeł. A. W a sile wska. Kraków 2015) rozdziały te, w tym samym układzie i bez istotnych różnic w treści, znalazły się w „dekameronie czwartym” jako „dni” 37, 38 i 39. Dla niniejszego tematu nie ma to jednak znaczenia. 
Wczesnochrześcijańskie katakumby, o których mowa, znajdują się przy kościele św. Pawła w Rabacie, miasteczku stanowiącym coś na kształt podzamcza warownej Mdiny.

Brydone opisuje jeszcze inną starożytną atrakcję Malty:

Jedna strona wyspy jest tak całkowicie ufortyfikowana przez samą naturę, że nie potrzebny był tu żaden ludzki kunszt. To wysoka skała, opadająca pionowo do morza na długości kilku mil. Wielka osobliwością tej strony wyspy są resztki głębokich kolein wyżłobionych przez wozy: drogi te kończą się nad przepaścią i pokazują, że wyspa w dawnych wiekach była o wiele większa niż obecnie ${ }^{16}$.

Brydone mówi tu o Misrah Ghar il-Kbir, miejscu popularnie zwanym Clapham Junction, położonym na wysokości klifów Dingli. Pochodzenie i wiek tych głębokich na około $60 \mathrm{~cm}$ kolein nie sa jasne; najpopularniejsza teoria wywodzi je z początku epoki brązu.

Podczas swojego półtorarocznego (?) pobytu Potocki z całą pewnością zwiedzał wyspę i poznał wszystkie jej osobliwości, ale nie po to na nia przybył. Celem jego było zaciagnięcie się do maltańskiej floty, którą tak opisuje Brydone:

Ich [kawalerów maltańskich] siły morskie składają się z czterech galer, trzech galeot, czterech okrętów o sześćdziesięciu działach i fregaty o trzydziestu sześciu. Poza tym mają pewną liczbę małych i szybkich łodzi żaglowych zwanych scampavias (dosłownie „zbiegowie”). Ich okręty, galery i fortyfikacje sa [...] dobrze wyposażone w znakomitą artylerię ${ }^{17}$.

Szkot miał szczęście bycia świadkiem wyjścia floty maltańskiej w morze:

Eskadra składała się $\mathrm{z}$ trzech galer, $\mathrm{z}$ których największa miała na pokładzie dziewięciuset ludzi, a dwie pozostałe po siedmiuset, a także trzech galeot i kilkunastu scampavias, tak nazwanych $z$ powodu nadzwyczajnej chyżości. Wszystkie te ogromne jednostki poruszane były wiosłami i posuwały się nad wyraz sprawnie. Na przedzie płynął admirał, a następni w zależności od piastowanej funkcji. Na wodzie roiło się od łódek, a wały i fortyfikacje pełne były gapiów. Port drżał od huku ciężkiej artylerii i wystrzałów $z$ dział wypływających galer i galeot. Jako że echo było nad wyraz gromkie, dawało to niezrównany efekt ${ }^{18}$.

W swoim opisie Brydone uchwycił schyłkowy moment świetności floty zakonnej, w owym czasie bowiem raison d'être zakonu maltańskiego zaczynała być nieco wątpliwa. Potęgę imperium osmańskiego we wschodniej części Morza Śródziemnego mocno nadwyrężyła bitwa pod Lepanto (1571), a klęska pod Wiedniem zapoczątkowała jego wypieranie $z$ Europy. Pod koniec XVIII wieku zagrożenie tureckie zmalało na tyle, że zredukowano śródziemnomorskie floty galer, także tę maltańską. Istotny problem stanowiło wciąż piractwo berberyjskie, ale flota zakonu była już tylko jedną z kilku pełniących funkcję morskiej „policji” Śódziemnomorza. W kontekście operujących tu marynarek wojennych innych krajów rolę okrętów maltańskich można uznać za wówczas marginalną.

B ryd o n e, op. cit., s. 344-345.

Ibidem, s. 360.

18 Ibidem, s. 341-342. Opisane przez Brydone’a wyjście maltańskiej eskadry na morze związane było z ekspedycją karną przeciw bejowi Tunisu, który naraził się królowi Francji. Bej nie chciał mianowicie wydać bez okupu korsykańskich niewolników, których był wziął, zanim jeszcze Francuzi objęli w posiadanie wyspę. 


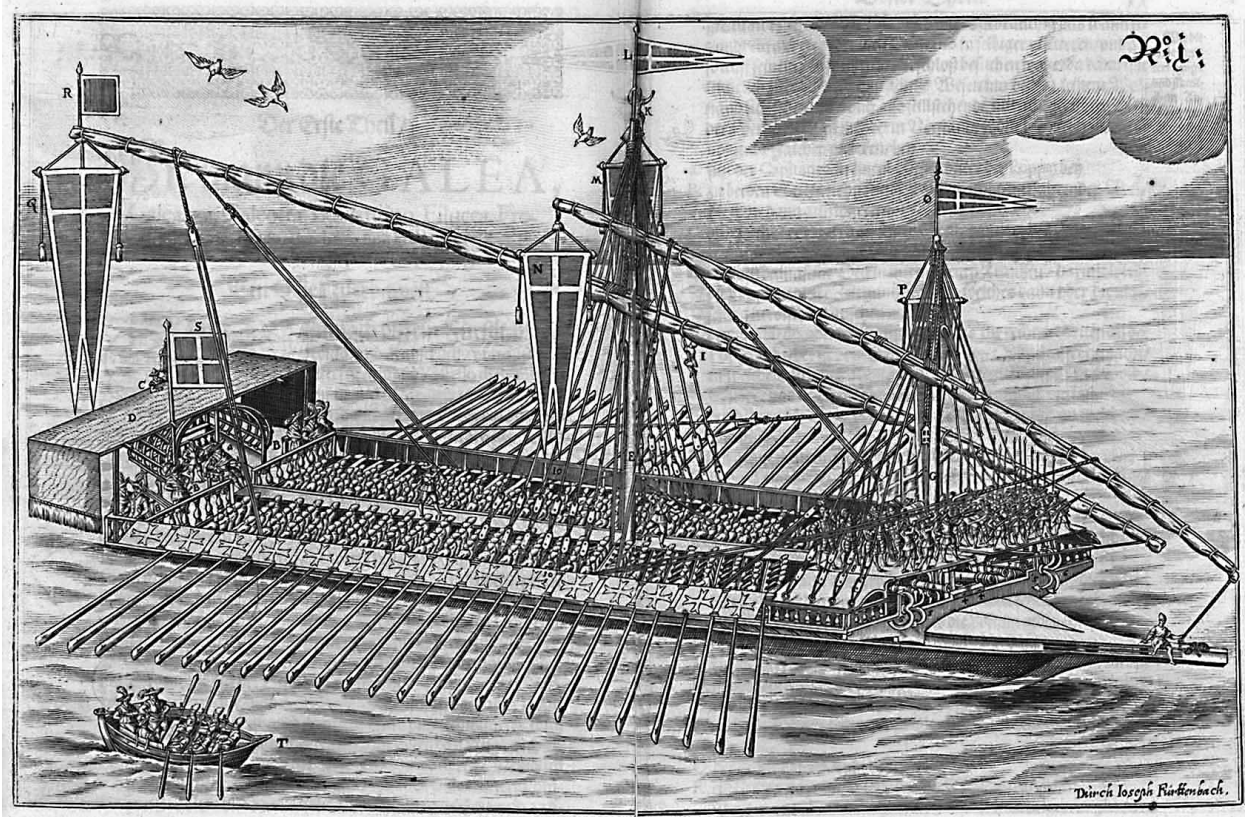

4. Galera zakonu maltańskiego. Rycina z dzieła Josepha Furttenbacha Architectura navalis. Das ist von dem Schiffgebäw, auff dem Meer und Seekusten zu gebrauchen [...] Ulm 1629

Flota maltańska 9 lat później nie różniła się znacznie od opisanej przez Szkota. Poza zdobna galerą magistralną (tzn. osobistą wielkiego mistrza) zakon dysponował prawdopodobnie czterema galerami, a więc galerą dowódcy flotylli, czyli malowaną na czerwono capitana, i galerami „San Luigi”, „San Pietro” i „Vittoria”19. Były to wszystko pełnowymiarowe jednostki zapewne o długości około $50 \mathrm{~m}$ i szerokości blisko 7 m, wymagające prawie 270 obsługujących je wioślarzy i do 100 marynarzy, dodatkowo obsadzone oddziałami wojska; podawana przez Szkota liczebność załóg wydaje się jednak przesadzona.

Trzeba tu wyjaśnić, że kawalerów maltańskich przebywało wówczas na wyspie tylko około 300, lecz zakon dawał pracę ogromnej rzeszy miejscowych i zamiejscowych marynarzy oraz żołnierzy.

Poza galerami zakon posiadał jeszcze, być może, trzy wspomniane przez Brydone’a galeoty, będące skrzyżowaniem żaglowców z pomniejszonymi galerami.

W skład floty stricte żaglowej w czasach Potockiego wchodziły trzy średnie liniowce: zwodowany na Malcie w roku 1765 flagowy okręt zakonu „San Giovanni” (czwarty już o tej nazwie), wyposażony w 64 działa i przenoszacy 522 ludzi pod komendą 9 zakonnych oficerów; następnie dysponujący analogiczną siłą ognia „San Gioacchino”, o długości 45 m, szerokości $12 \mathrm{~m}$ i zanurzeniu 5,6 m, a także „San Zaccaria”, przewożący 400 marynarzy i żołnierzy pod dowództwem 10 ofi-

19 Zob. R. L. D a u b e r, Die Marine des Johanniter-Malteser-Ritter-Ordens. 500 Jahre Seekrieg zur Verteidigung Europas. Graz 1989, s. 322, 328. 
cerów $^{20}$. Zakon dysponował też fregata „Santa Maria” ${ }^{21}$ o 36 działach. Pod koniec służby Potockiego w maltańskiej flocie statki „San Giovanni” i „San Gioacchino” zostały sprzedane królowi Neapolu. Spowodowane to było, z jednej strony, kłopotami finansowymi zakonu, $\mathrm{z}$ drugiej - planową akcją zastępowania okrętów wojennych statkami handlowymi, które, zdaniem wielkiego mistrza Emmanuela de Rohana, lepiej wpisywały się w sytuacje panującą wtedy na Morzu Śródziemnym.

W opowieściach składających się na jego dzieło, Potocki ukazuje inny, wcześniejszy okres, kiedy na Morzu Śródziemnym królowały galery, a nie okręty żaglowe:

kawaler Toledo objął główne dowództwo nad galerami, brat zaś jego przysłał mu na wydatki sześćkroć sto tysięcy piastrów. Zakon miał wówczas sześć galer, do których Toledo dwie własnym kosztem uzbroił. Kawalerów zebrało się sześciuset. Była to najpierwsza młodzież Europy ${ }^{22}$.

Dowództwo, o którym tu mowa, sprawował generał galer, druga osoba po admirale floty zakonnej. $Z$ zacytowanego fragmentu Rękopisu znalezionego $w$ Saragossie wynika, że kawaler Toledo własnym sumptem powiększył flotę maltańską o dwa dodatkowe statki, co było przedsięwzięciem nad wyraz kosztownym. Samego utrzymania dwóch takich okrętów podjął się w roku 1668 Hieronim Augustyn Lubomirski, ale rychło z tego zrezygnował ${ }^{23}$. Potocki pisze dalej:

Naówczas zaczynano we Francji dawać wojsku mundury, co dotąd nie było jeszcze w zwyczaju. Toledo dał nam mundur na wpół francuski, a na wpół hiszpański. Nosiliśmy purpurowy kaftan, czarną zbroję z krzyżem maltańskim na piersiach, krezę i hiszpański kapelusz ${ }^{24}$.

Istotnie, w XVIII wieku, czyli w czasach Potockiego, jako wojenny ubiór maltańczyka na morzu wszedł w użycie czerwony frak, który w kroju z lat siedemdziesiątych XIX wieku funkcjonuje do dziś jako uroczysty mundur maltański. Stanowił on nawiązanie do szkarłatnych tunik $z$ białym krzyżem noszonych przez zakonników w boju już we wczesnym średniowieczu.

Przyjmuje się, że Potocki jako ochotnik brał udział w morskich wyprawach kawalerów, ale nie wiadomo, czy służył na galerach, których epoka dobiegała wtedy już końca, czy na żaglowcach. Fakt, że w kontekście maltańskim w Rękopisie znalezionym $w$ Saragossie mowa jest wyłącznie o galerach, pozwala jednak na ostrożny wniosek, że to właśnie $z$ nimi hrabia zawarł bliższą znajomość.

Służba morska w zakonie podzielona była na 6-miesięczne (dla galer) lub roczne (dla żaglowców) okresy, przez wzgląd na tradycję sięgającą jeszcze jerozolimskich czasów nazywane „karawanami”. Bez odbycia czterech takowych na galerach, lub dwóch na żaglowcach, młodzi maltańczycy, zwani w okresie służby karawanistami, caravanisti, nie mieli szans na otrzymanie komandorii, która poza prestiżem mogła przynieść niezły dochód. 
W roku1780 Potocki formalnie wstapił do zakonu, opłacił wpisowe, czyli passaggio, i swoje morskie ćwiczenia przeżywał już jako karawanista.

Nic nie wiadomo o tym, by w owym czasie zakon angażował się w jakieś większe morskie starcia.

Kawaler [Toledo] dowodził główną galerą, wziął mnie więc na swój pokład i krążyliśmy po morzu przez cztery miesiące, nie zaszkodziwszy wiele Berberyjczykom, którzy na lekkich statkach łatwo przed nami umykali ${ }^{25}$.

Kto wie, czy ten fragment opowieści naczelnika Cyganów nie odzwierciedla doświadczenia samego Potockiego?

Służba na galerze wymagała znacznego samozaparcia choćby dlatego, że wioślarze (zarówno przykuci do wioseł niewolnicy oraz jeńcy, jak i zawodowi wioślarze, zwani buonavogli) załatwiali swoje potrzeby naturalne nie ruszając się z ławek. Poza tym na pokładzie panowała żelazna dyscyplina, o czym świadczy np. następujący wyimek $\mathrm{z}$ zakonnego regulaminu dotyczący galer:

Jako że nie ma nic ważniejszego aniżeli zapobieganie sposobności do kłótni w miejscu tak niebezpiecznym jak galera, nakazano, iż jeśli którykolwiek z braci, po ślubach bądź nowicjusz, rzeknie coś, co mogłoby uwłaczać honorowi innego brata, po ślubach lub nowicjusza, pozbawionym zostanie habitu i obwołanym niezdolnym do jego odzyskania; jeśli zaś kogoś szturchnie, uderzy laską lub też chwyci [przy nim] za jakąkolwiek broń, to mimo że żadnego z braci nie zrani, nie tylko pozbawionym zostanie habitu, ale też wydanym zostanie świeckim jako zły, niezdolny do życia [we wspólnocie] żołnierz, łamiący wojskową dyscyplinę 26 .

„Pozbawienie habitu” było ceremonialnym wydaleniem delikwenta $\mathrm{z}$ zakonu maltańskiego.

Zakazy obowiązujące na morzu zmuszały kawalerów do rozwiązywania swoich spraw honorowych na lądzie:

Malta jest, być może, jedynym krajem świata, gdzie pojedynki są prawnie dozwolone. Jako że cała ich konfraternia oparta została pierwotnie o dzikie i romantyczne zasady rycerskości, kawalerowie maltańscy uznali zakaz żądania i dawania satysfakcji za niezgodny z jej normami; obłożyli jednak pojedynki ograniczeniami, mającymi na celu złagodzenie ich skutku. Są one osobliwe: pojedynkujący się zobowiązani są do rozstrzygania swoich sporów na jednej szczególnej uliczce w mieście, a jeśli zechca pojedynkować się gdziekolwiek indziej, odpowiadają przed prawem. Co jednak jest nie mniej osobliwe, i co przemawia na ich korzyść, to obowiązek, pod rygorem kary, schowania broni, jeśli nakaże im to kobieta, ksiądz lub inny kawaler ${ }^{27}$.

Mowa tu o znajdującej się w Valletcie wąskiej uliczce o nazwie Strait Street (malt. Triq Id-Dejqa), w czasach Potockiego zwanej Strada Stretta. Czytelnicy Rękopisu znalezionego $w$ Saragossie pamiętają zapewne opowieść komandora Toralvy, przytaczana przez Błażeja Hervasa, potępionego pielgrzyma:

według naszych zwyczajów pojedynki są zakazane na Malcie, z wyjątkiem Ciasnej Uliczki, przejścia, na które nie wychodzi żadne okno. Uliczka ma tyle szerokości, ile potrzeba dla dwóch ludzi, którzy chcą

Ibidem, s. 263-264.

Regulamin, część zatytułowana Of the Galleys, pkt 19. Cyt. za: R. A. V e r to t, The History of the Knights of Malta. T. 2. London 1728, s. 187.

Brydon e, op. cit., s. 362. 
złożyć się i skrzyżować szpady. Żaden z nich jednak nie może się cofnąć. Przeciwnicy stają w poprzek uliczki, przyjaciele ich zaś zatrzymują przechodzących, ażeby im nie przeszkadzali. Zwyczaj ten zaprowadzono niegdyś dla zapobieżenia morderstwom, człowiek bowiem, który wie, że ma nieprzyjaciela, nie przechodzi przez Ciasną Uliczkę, gdy zaś morderstwo gdzie indziej zostaje popełnione, niepodobna już podać je za pojedynek.

Wreszcie, pod karą śmierci, nie wolno ze sztyletem przechodzić przez Ciasną Uliczkę. Widzisz więc, że pojedynek jest nie tylko tolerowany, ale nawet dozwolony na Malcie, chociaż wyraźnie pozwolenie to nie jest ogłoszone ${ }^{28}$.

Wróćmy jednak do Brydone’a, który poczynił ciekawe obserwacje dotyczące narodowości wchodzących w skład tego międzynarodowego towarzystwa:

Wszyscy owi kawalerowie i komandorowie wyglądają na dżentelmenów i światowców; nie spotkaliśmy się z żadną skrajnością. Dzięki styczności i bliskiemu obcowaniu z innymi śmiesznostki i przesądy typowe dla każdej nacji stopniowo osłabły i zanikły. Interesująca jest obserwacja wpływu owego obcowania na ludzi, którzy składają się na tę mieszankę. Podrygiwanie Francuza, dumne kroczenie Niemca i sztywny chód Hiszpana przemieszały się w tak niewielkich proporcjach, iż żadna z tych manier już nie razi - mimo że każda nacja zachowuje coś ze swoich pierwotnych cech. Zanikła tylko przesada; wciąż zatem łatwo odróżnić mieszkańców południowej i północnej strony Pirenejów, jak i tych ze wschodniej i zachodniej strony Renu. Bo choć paryżanin w dużym stopniu utracił swoją pozę, Hiszpan swoją mrukliwość i powagę, Niemiec swoją sztywność i dumę, jednak wciąż we wszystkich z nich widać Niemca, Francuza i Hiszpana; zniknęła tylko karykatura, która kiedyś czyniła ich śmiesznymi ${ }^{29}$.

Refleksje dotyczące narodowych cech kawalerów snuł także Potocki; odkładały się one w jego pamięci i wzbogaciły potem Rękopis znaleziony $w$ Saragossie:

zachowanie tajemnicy nie zgadza się z charakterem kawalerów francuskich, a przynajmniej, że niesłychanie rzadko się zdarza, żeby który z nich łączył dyskrecję z innymi świetnymi przymiotami, jakie ich w ogóle cechuja. $Z$ tego wynikło, że młodzi ludzie tej nacji, przyzwyczajeni w innych krajach do wielkiego powodzenia u kobiet, na Malcie muszą wdawać się z dziewczętami ulicznymi. Kawalerowie niemieccy, zresztą mniej liczni, najwięcej mają szczęścia u kobiet „onorate” i zawdzięczają to, jak sądzą, swej biało-różowej cerze. Za nimi idą Hiszpanie, których uczciwy i pewny sposób myślenia główna jest zaletą.

Kawalerowie francuscy, zwłaszcza zaś karawaniści, mszczą się na kobietach „onorate”, drwiąc z nich wszelkimi sposoby i odkrywając ich tajemne miłostki, ponieważ jednak żyją zawsze osobno i nie chcą uczyć się włoskiego języka, którym cały kraj mówi, nikt przeto nie zważa na ich plotki ${ }^{30}$.

Owe onorate (z włoskiego „poważane”) to kobiety, które według słów Potockiego „zasługują na ten tytuł przez przyzwoitość w postępowaniu i [...] przez tajemnicę, jaką osłaniają swoje miłostki”31.

Swobodne prowadzenie się kawalerów maltańskich potwierdza Brydone w swoim opisie wypłynięcia floty maltańskiej na morze:

W każdej galerze było trzydziestu kawalerów, dających znaki swoim kochankom, które łkały na bastionach z powodu rozstania; owi panowie bowiem równie mało przejmują się swoimi ślubami czystości, co księża i spowiednicy ${ }^{32}$.

Można, oczywiście, wziąć poprawkę na sceptycyzm protestanta w stosunku do

Ibidem, s. 237.

B ryd o ne, op. cit., s. 342 . 
katolików; tym niemniej luźne obyczaje, bądź co bądź, zakonników (lub kawalerów odbywających nowicjat) nie są niczym zaskakującym, jeśli zna się XVIII-wieczną historię zakonu maltańskiego.

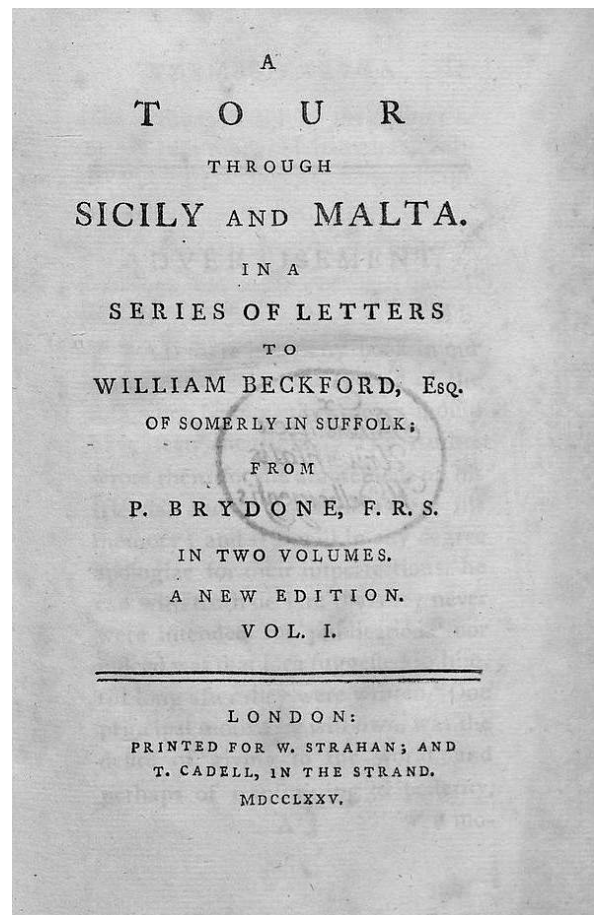

5. Cytowane dzieło Patricka Brydone’a

Jakieś ziarno prawdy zapewne kryje się w stwierdzeniu niechętnego zakonowi najemnego żołnierza, który służył w regimencie maltańskim właśnie w latach 1780-1782 i opublikował pod pseudonimem Carasi swoje wrażenia: że na wyspie prostytucji oddawały się wówczas, amatorsko lub zawodowo, dwie na trzy jej mieszkanki $^{33}$.

Potocki zszedł na ląd w stolicy, Valletcie, w piątym roku panowania siedemdziesiątego wielkiego mistrza suwerennego rycerskiego i szpitalnego zakonu św. Jana Jerozolimskiego, Emmanuela de Rohan-Polduc. Ten pochodzacy ze starego i wpływowego francuskiego rodu arystokrata pośrednio przejął władanie nad wyspa $^{34}$ od Portugalczyka Manuela Pinta da Fonseca, pierwszego wielkiego mistrza zakonu, który w jego herbie zaczął używać zamkniętej korony, by podkreślić niezależność i znaczenie swojego międzynarodowego państewka. Pinto rządził wyspa przez 32 lata (1741-1773), skonfliktowany ze starą maltańską arystokracją, z KoKnights of Malta and Their Morals; Also Containing Descriptions of the Nature, Products of the Island, and the Customs of Its Inhabitants opublikowano na Malcie w 2010 roku. 
ściołem (wygnał z Malty jezuitów) i z ciemiężoną podatkami ludnością. Brydone zostawił nam taki oto opis Pinta, którego miał okazję poznać osobiście:

Jest staruszkiem rozsądnym i trzeźwo myślącym, co w jego wieku jest niezmiernie rzadkie. Mimo że ma sporo ponad dziewięćdziesiąt lat, zachował całkowitą sprawność umysłu. Nie na żadnych ministrów i wszystkim zajmuje się sam; informowany jest też natychmiast o wszystkich najdrobniejszych wydarzeniach. Bez pomocy pokonuje schody, a nawet drogę do kościoła i wygląda, jakby miał przed soba jeszcze wiele lat życia. Jego służba i dwór mają charakter bardzo pański, a jako wielki mistrz Malty panuje on niepodzielnie i ma więcej władzy aniżeli większość udzielnych książąt. Tytułuje się Najjaśniejszym Panem i Eminencją ${ }^{35}$.

Brydone najwyraźniej zasięgną języka co do mechanizmów władzy wielkiego mistrza i nastrojów panujących w jego otoczeniu, ponieważ opisuje to wszystko dość szczegółowo:

jako że dysponuje wszystkimi lukratywnymi urzędami, postępuje ze swoimi ciałami doradczymi, jak chce; poza tym przewodniczy wszystkim ciałom, na które składa się jurysdykcja tego małego narodu, i ma w nich podwójny głos. Odkąd obrano go wielkim mistrzem, oprócz przeoratów i innych dochodowych urzędów rozdał już 126 komandorii, $\mathrm{z}$ których niektóre warte były ponad 2000 funtów rocznie. Co pięć lat ma też do dyspozycji dwadzieścia komandorii i jeden przeorat, a jako że zawsze są na nie chętni, wszyscy bardzo mu nadskakują.

Wybiera go [tj. wielkiego mistrza] komitet złożony z dwudziestu jeden kawalerów, który to komitet nominowany jest przez te siedem narodów, po trzech członków z każdego. Wybór musi być dokonany przed upływem trzech dni od śmierci poprzedniego wielkiego mistrza i podczas tych trzech dni mało kto na Malcie kładzie się spać. Wszystko jest wtedy kabałą i intrygą; większość kawalerów nosi maski, żeby nie dowiedziano się, do jakich koterii należą. Kiedy wybory się kończą, wszystko wraca do normy ${ }^{36}$.

Brzmi to wszystko bardzo świecko i, jak z tego widać, temu religijnemu zgromadzeniu było w owym czasie daleko do surowego życia konwentu.

Wspomniany następca Pinta, Francuz de Rohan, który na wyspie był najwyższym przełożonym Potockiego, należał do władców zupełnie innego typu. Przede wszystkim starał się naprawić nadwątlone przez poprzedników stosunki zakonu z ludnością wyspy i według przekazów udało mu się zyskać jej szacunek. Dorobił się też własnego miasta, Città Rohan (obecnie Żebbuġ), któremu nadał miejskie prawa i swój herb. Już po opuszczeniu przez Potockiego wyspy ukazało się zamówione przez wielkiego mistrza Del Dritto Municipale di Malta, później znane jako Codice de Rohan, imponujący rodzaj zbioru praw i konstytucji zakonu oraz Malty, w którym - jak się uważa - widoczny jest wpływ oświecenia. De Rohan nie zrezygnował jednak $z$ wystawnego dworu, gdzie usługiwało mu 12 paziów, ani $z$ bogato zdobionej magistralnej galery.

Ciekawe wspomnienie de Rohana i interesujące świadectwo hierarchicznego ceremoniału na jego dworze za czasów Potockiego zostawił nam Niemcewicz:

Był to mąż pół wieku liczący, przystępny i miły. Daje mu się tytuł eminenza. Przyjmuje wieczorem, pokazując się trzy razy: raz dla kawalerów, drugi raz dla komandorów, trzeci raz na koniec dla bailly, najwyższych urzędników zakonu; każde pokazanie się nie trwa [dłużej] jak dwie minuty, lecz między jednym i drugim pół godziny upływa ${ }^{37}$. 


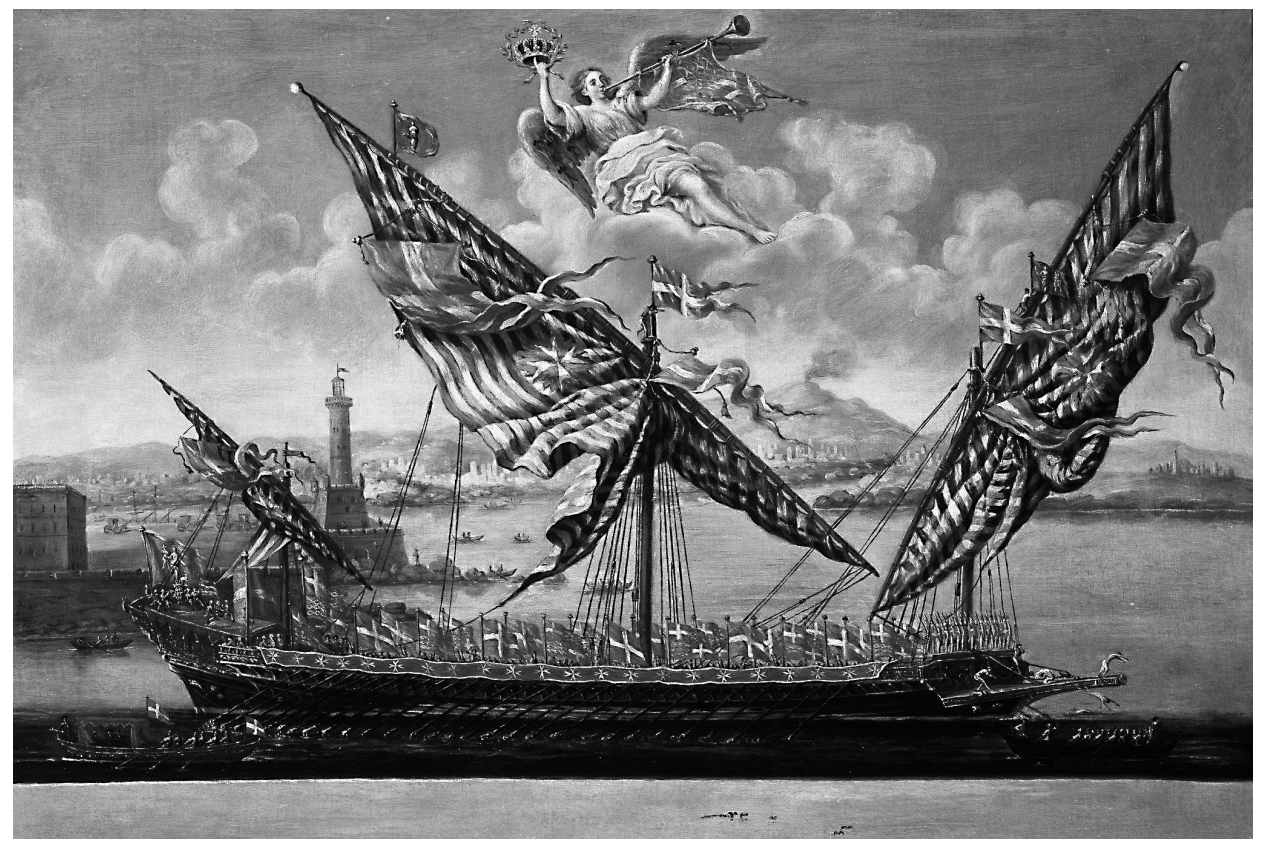

6. Galera wielkiego mistrza Emmanuela de Rohan-Polduc. Szkoła neapolitańska

Od służby na magistralnym dworze zaczyna się w Rękopisie znalezionym $w$ Saragossie spowiedź komandora Toralvy:

Wstąpiłem do zakonu maltańskiego, nie wyszedłszy jeszcze z lat dziecinnych, zapisano mnie bowiem do służby jako pazia. Opiekunowie, jakich miałem u dworu, wyjednali dla mnie w dwudziestym piątym roku dowództwo galery, wielki mistrz zaś, rozdając w rok później urzędy, powierzył mi najlepszą komandorię Aragonii. Mogłem więc i dziś jeszcze mogę ubiegać się o najpierwsze godności w zakonie; ale ponieważ dopiero w późnym wieku można je osiagnnąc i ponieważ tymczasem nic nie miałem do czynienia, poszedłem więc za przykładem naszych baillich, którzy może powinni mi byli lepszy nastręczyć, jednym słowem, oddałem się miłostkom ${ }^{38}$.

Czy sam Potocki oddawał się miłostkom? Trudno powiedzieć. Nie przeszedł do historii jako casanova, ale Maltankom mógł się podobać. A z lektury Rękopisu znalezionego $w$ Saragossie wynika, że dobrze orientował się w erotycznych obyczajach na wyspie:

Nadszedł Wielki Piątek. Wiesz, że według zwyczaju hiszpańskiego podaje się tego dnia wodę święconą uwielbianej kobiecie, idąc za nią z kościoła do kościoła. Pod pewnym względem pobudza do tego zazdrość i obawa, aby ktoś inny nie podał wody i tym sposobem nie starał się zawrzeć znajomości. Zwyczaj ten wprowadzono również na Maltę. Stosownie do niego, udałem się za pewną młodą kobietą „onorata”, z którą od kilku lat zostawałem w związkach ${ }^{39}$.

Czym zajmował się hrabia w czasie wolnym od służby wojskowej? Można bezpiecznie założyć, że zawarł znajomość z tutejszym teatrem. Rosset i Triaire piszą 
o Operze ${ }^{40}$, ale za bytności Potockiego na Malcie opery jako takiej jeszcze nie było. Istniał już natomiast Teatro Pubblico, zbudowany przez wielkiego mistrza Antonia Manoela de Vilhene jeszcze w roku 1731, oficjalnie ad honestam populi oblectationem, nieoficjalnie zaś, by krewcy młodzi ludzie mogli choć w taki sposób dać upust swojej energii. Przedstawienia organizowali bowiem sami kawalerowie, zwłaszcza włoscy; początkowo oni też byli aktorami, wcielając się również w role kobiece. Teatr funkcjonuje zresztą do dziś pod nazwą Teatr Manoel (ang. The Manoel Theatre, malt. It-Teatru Manoel) i jest zabytkiem klasy zerowej.

Rosset i Triaire sugerują także, że Potocki odwiedzał tutejszą bibliotekę ${ }^{41}$. Jest to, oczywiście, nader prawdopodobne. Biblioteka owa została uroczyście otwarta jako Bibliotheca Publica przez de Rohana w roku 1776, a więc trzy lata przed przybyciem Potockiego. W rzeczywistości istniała już od 15 lat jako prywatna kolekcja kawalera Louisa Guérina de Tencin, który kupił był 9700 woluminów po zmarłym hiszpańskim grandzie, kardynale Joaquínie Fernándezie de Portocarrero, i wraz ze swoim własnym, równie wielkim, zbiorem udostępnił publiczności w budynku zwanym Il Forfantone, znajdującym się przy ówczesnej Strada San Giorgio w Valletcie. Obiekt ten znacznie ucierpiał w trakcie ostatniej wojny i został po niej gruntownie przebudowany; obecny jego adres to Republic Street nr 251. Bibliotekę zakonu przeniesiono zaś w 1812 roku na Old Treasury Street nr 36, gdzie mieści się do dzisiaj jako Biblioteka Narodowa Malty (malt. Bibljoteka Nazzjona-

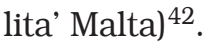

Potocki mógł także biernie uczestniczyć w mniej wyrafinowanych widowiskach, np. w hucznie obchodzonym 3-dniowym karnawale, czy w podobnym świętowaniu jakiejś szczególnej okazji, zwanym Babarro, w pierwszomajowych zawodach we wspinaniu się na namydlony słup ustawiony przed Pałacem Wielkich Mistrzów, czy w zawodach szybkobiegaczy ścigających się wzdłuż Strada San Giorgio na dystansie około $1000 \mathrm{~m}$, organizowanych na św. Jana ${ }^{43}$. Wielcy mistrzowie dbali, by stosownie do śródziemnomorskiego temperamentu hucznie fetowano też wszelkie inne święta kościelne.

Wszyscy, którzy w naszych już czasach bywali na Malcie, zapewne zetknęli się z typowymi dla wyspy barwnymi lokalnymi obchodami uroczystości religijnych. Prawie nie ma tam dnia, by któraś miejscowość nie była przystrojona szkarłatnymi flagami z białym krzyżem, których zakonne pochodzenie już dawno, przypuszczalnie, zatarło się mieszkańcom w pamięci. Są to dalekie echa wymienionych tu świąt.

Potocki bywał zapewne widzem popularnych wśród kawalerów, dość osobliwych gonitw konnych, tak opisanych przez Brydone'a:

Odbywają się one bez użycia siodeł, uzd, palcatów i ostróg, a mimo to konie rozwijają znaczną szybkość i dają widzom wiele uciechy. Od kilku tygodni są przyzwyczajane do toru i mimo że wyścigi przebiegają na kamienistym gruncie, rzadko dochodzi do wypadków. W podobny sposób cztery razy do

Ross et, Triaire, op. cit., s. 76.

Ibidem.

42 Zob. na stronie: https://vassallohistory.wordpress.com/some-houses-in-valletta. Data dostępu: 23 V 2018.

43 Zob. W. Por ter, History of the Knights of Malta, or the Order of the Hospital of St. John of Jerusalem. T. 2. London 1858, s. 269-270. 
roku ścigają się osły i muły. Jeźdźcy wyposażeni są w urządzenie przypominające szewskie szydło, którym kłują swojego wierzchowca, gdy jest zbyt leniwy ${ }^{44}$.

Współcześni Maltańczycy pasjonują się, co prawda, raczej wyścigami kłusaków, ale tradycyjne gonitwy na oklep wciąż są organizowane raz w roku na wzgórzu Saqqajja w Rabacie, przy okazji fiesty pod wezwaniem św. Piotra i św. Pawła (malt. il-Festa tal-Imnarja).

Przyszły autor Rękopisu znalezionego w Saragossie opuścił wyspę w 1781 roku. Sentyment do zakonu mu pozostał i Potocki czuł się maltańczykiem, o czym świadczy fakt, że planując ożenek, w roku 1784 prosił wielkiego mistrza de Rohana o przywilej noszenia zakonnego insygnium, tzw. krzyża devotionis ${ }^{45}$, który sygnalizował związek ze zgromadzeniem, ale nie zobowiazywał do przestrzegania zakonnych ślubów ${ }^{46}$. Wpadł też na osobliwy pomysł połączenia Orderu św. Stanisława z traktowanym niekiedy jak order Krzyżem Maltańskim, co nie spodobało się władzom zgromadzenia ${ }^{47}$.

De Rohan panował jeszcze długo, przeżywszy cios, który zadała „Malcie” rewolucja francuska i utrata znacznej części dochodów zakonu. Miał chyba świadomość, że wraz z nim nieodwołalnie kończy się pewna epoka, bo kiedy, osłabiony wylewem, umierał w roku 1797, miał jakoby powiedzieć: „Tak czy owak, jestem ostatnim wielkim mistrzem - przynajmniej zakonu tak znamienitego i niezależnego". Istotnie, jego następca, Ferdynand von Hompesch, oddał wyspę wojskom Napoleona niemal bez wystrzału, wyemigrował i abdykował, a w „Malcie” nastapił zamęt; potem zaś zakon popadł w marazm i przez dłuższy czas właściwie wegetował, zanim się odrodził w innej formie - tej, którą znamy dzisiaj ${ }^{48}$.

\section{Abstract \\ TADEUSZ WOJCIECH LANGE Adam Mickiewicz University, Poznań \\ JAN POTOCKI'S MALTA}

In Count Jan Potocki's biography we find a period of his longer stay on Malta. Unfortunately, he left us neither a description of the island at that time, nor one of the Order of Malta to which he was finally admitted. Potocki's knowledge on Malta and the reality he experienced are confirmed only by the members of the Order featuring in Rękopis znaleziony $w$ Saragossie (The Manuscript Found in Saragossa) and their remarks about the life in the Order. However, accounts of travellers (e.g. of the Briton Patrick Brydone) from Potocki's times make it possible to reconstruct the then island and the Order of Malta. The essay is an attempt at presenting Malta, its inhabitants and the Knights at the time Potocki stayed there.

Bryd on e, op. cit., s. 368.

Zob. Ross et, Triaire, op. cit., s. 107-108.

P. Cz e rw iń ski (Zakon maltański i stosunki jego z Polska na przestrzeni dziejów. Londyn 1963, s. 162) pisze, że w ówczesnej Polsce taki przywilej noszenia zakonnego krzyża per Gratiam Magistralem, czyli „Z łaski wielkiego mistrza” miał m.in. także biskup I. Krasicki i wojewoda bełski, poeta, dramatopisarz, tłumacz i mineralog M. J. Borch. Zob. też A. Rot te r m u nd, Kawalerowie maltańscy $w$ Polsce $w$ XVIII i XIX wieku. W zb.: Zakon maltański $w$ Polsce. Red. S. K. Ku c zy ń s k i. Warszawa 2000, s. 148.

Zob. Rottermund, op. cit., s. 148, przypis 210.

Tzn. federacji związków narodowych. 